[Agr. Biol. Chem., Vol. 33, No. 10, p. 1483 1490, 1969]

\title{
An Inverse Relationship between Liver Arginase Activity and Urea Excretion in Rats*
}

\author{
By Shuhachi Kiriyama** and Hiroyuki Iwao \\ The National Institute of Nutrition, 1 Toyamacho, \\ Shinjukuku, Tokyo \\ Received April 14, 1969
}

\begin{abstract}
Liver arginase activity in rats fed graded levels of diammonium citrate in high and low casein diets, was measured with simultaneous determination of urea excretion. The arginase activity changed inversely with the urea excretion.

Moreover, when the amino acid balance was quantitatively changed by varying threonine level alone, a similar relationship between total liver arginase activity and urea excretion was again observed.

From these results, the early teleological assumptions are most unlikely in that liver arginase activity increases with the decrease in dietary protein quality and that the change in activity can be used as an index of dietary protein quality.
\end{abstract}

The parallelism between urea excretion and total liver arginase activity of rats has been repeatedly confirmed, ${ }^{1 \sim 31}$ although the positive correlation between these 2 parameters was that drawn only from the observations on the responses to the changes in dietary level of a given protein (mostly casein). However, it was shown that increased urea excretions caused by feeding lower quality proteins or amino acid mixtures limited only in tryptophan content were not accompanied by an increased total activity of liver arginase of the rats: ${ }^{43}$ arginase activity was not directly related to the extent to which the urea synthetic pathway was utilized. Therefore, we assumed

* A part of this study was presented at the 19 th Annual Meeting of the Japanese Society of Food and Nutrition in 1965.

** Present address: Department of Nutrition, School of Medicine, Tokushima University, 3 Kuramotocho, Tokushima.

1) K. Muramatsu and K. Ashida, Nippon Nogeikagaku Kaishi, 25, 725 (1955).

2) K. Ashida and A. E. Harper, Proc. Soc. Exp. Biol. Med., 107, 151 (1961).

3) R. T. Schimke, J. Biol. Chem., 237, 459 (1962).

4) S. Kiriyama, H. Iwao and K. Ashida, Agr. Biol. Chem., 31, 671 (1967). from the results of our previous experiments ${ }^{4}$ and of the other workers, ${ }^{1-3,5 \sim 71}$ that the substantial level of liver arginase is not necessarily determined only by the metabolic needs for urea biosynthesis, and that urea excretion generally depends upon the flow rate of urea-cycle substrates into the cycle.

Urea excretion appears susceptible to a variety of external factors other than the change in protein level of diet: vitamin deficiency, ${ }^{8-11}$ fasting, ${ }^{121}$ or caloric deficien$\mathrm{cy},{ }^{131}$ change in protein quality, ${ }^{4,14 \sim 17)}$ and an

5) H. D. Lightbody and A. Kleinman, J. Biol. Chem., 129, 71 (1939).

6) J. Mandelstam and J. Yudkin, Biochem. J., 51, $681(1952)$

7) R. T. Schimke, J. Biol. Chem., 237, 1921 (1962).

8) B. Sure and Z.W. Ford, Jr., J. Nutrition, 24, 405 (1942).

9) J. R. Beaton, R. M. Ballantyne, L. E. Lau, A. Steckley and E.W. McHenry, J. Biol. Chem., 186, $93(1950)$.

10) J.R. Beaton, J. L. Beare, J. M. White and

E. W. McHenry, ibid., 200, 715 (1953).

11) W. W. Hawkins, M. L. MacFarland, and E. W. McHenry, ibid., 166, 223 (1946).

12) K. Muramatsu and K. Ashida, Nippon Nogeikagaku Kaishi, 31, 603 (1957).

13) S. Kiriyama and K. Ashida, J. Japan. Biochem. Soc., 32, $185(1960)$. 
additional ingestion of ammonium nitrogen in addition to the sufficient supply of dietary protein. However, there are few instances in which the correlation between urea excretion and liver arginase activity was intentionally pursued when affected by the factors other than dietary protein level.

The present experiments were undertaken to examine whether or not there is an additional indication to show the lack of parallelism between urea excretion and total liver arginase activity as observed in previous studies."

\section{EXPERIMENTAI}

In order to modify urea excretion, diammonium citrate (DAC) was used in place of increasing protein level. Diammonium citrate does not produce ammonia toxicity when it is orally administered together with other dietary ingredients as already shown by Lardy and Feldott ${ }^{17,18}$ and Rose et al.19! The latter authors showed, using rats, that nitrogen from DAC was equally or more efficiently utilized than that from nonessential amino acids (glutamic acid or glycine) when these $N$ sources were included isonitrogeneously in the diets containing $8 \%$ essential amino acid mixture.

Experiment 1. Thirty-day-old male rats of Wistar strain, which had been fed a $20 \%$ casein diet for 5 days, were divided into 5 groups of 5 animals each and given test diets for 14 days. Urine was collected from individual rat for the last 3 days of this period. Environmental temperature was kept at $24^{\circ} \pm 2^{\circ}$ under air conditioning. The basal diet used in experiment 1 contained the following amounts per $100 \mathrm{~g}$ of test

14) S. Kiriyama and K. Ashida, J. Nutrition, 82, 127 (1964).

15) S. Kiriyama and H. Iwao, Agr. Biol. Chem., 28, 307 (1964).

16) S. Kiriyama, Y. Yagishita, T. Suzuki and H. Iwao, ibid., 31, 743 (1967).

17) H. A. Lardy and G. Feldott, J. Biol. Chem., 179, 509 (1949).

18) H. A. Lardy and G. Feldott, ibid., 186, 85 (1950).

19) W. C. Rose, L. C. Smith, M. Womack and M. Shane, ibid., 181, 307 (1949). diet: casein, 8; soybean oil,* 5; salt mixture-B,** 4; vitamin mixture,*** 1 ; choline chloride, 0.15 ; and pregelatinized starch made from corn $\beta$-starch, 81.9. To prepare the test diets, $0,2,4,6$, or $8 \%$ of pregelatinized starch was replaced by corresponding amounts of DAC. At the end of the experimental period, the rats were decapitated and bled. Rapidly excised liver was placed in crushed ice, blotted with filter paper, and weighed. Exactly $2 \mathrm{~g}$ of the tissue was immediately homogenized with $20 \mathrm{ml}$ of ice-cold distilled water for one minute in an iced Waring blender, then filtered through doubly folded gauze. This primary homogenate was further diluted 100 times with ice-cold distilled water just before the arginase assay which was initiated within $3 \mathrm{hr}$ after the each primary homogenate had been prepared. The assay procedure employed was the same throughout the experiments as previously described.4 Urea was determined for the urine and for the reaction mixture in arginase assay by the method of Engel and Engel.201

Experiment 2. From 2 main facts that the liver arginase activity generally increases with both the level and nutritive value of dietary protein, we considered that arginase protein was passively synthesized depending upon the amounts of amino acid supply which became available from the diet for body protein synthesis. Under the dietary condition of the experiment 1, body protein synthesis of the rats would have been kept below their latent proteinretaining capacity, because of their limited protein intakes due to low dietary protein level, consequently the synthesis of arginase protein would have been comparatively restricted. Experiment 2 was, therefore, planned to see the arginase responses to an excessive urea excretion, in which rats were fed the sufficiently high protein diets simultaneously supplemented with graded levels of DAC.

Each group consisted of 5 male rats of Wistar strain (weighing 120 to $140 \mathrm{~g}$ ) and was given the

* Fat soluble vitamins had been incorporated into soybean oil prior to preparing the diet to provide the following amounts per $100 \mathrm{~g}$ of diet: vitamin $\mathrm{A}$, $600 \mathrm{IU}$; vitamin D, $60 \mathrm{IU}$; and $\alpha$-tocopherol, $10 \mathrm{mg}$, respectively.

** A. E. Harper, J. Nutrition, 68, 405 (1959).

*** This was essentially the same as Harper's mixture except that lactose was used as its bulking agent.

20) M. G. Engel and F. L. Engel, J. Biol. Chem., 167, 535 (1946). 
TABLE I. COMPOSITION OF TEST DIETS USED IN EXPERIMENT 2

\begin{tabular}{lrrrrr}
\multicolumn{1}{c}{ Constituent } & Basal & & & & \\
& A & B & C & D & E \\
Casein & ${ }^{\circ}$ & 8 & 8 & 8 & $\%$ \\
$\alpha$-Starch & 25 & 35 & 45 & 25 & 25 \\
Soybean oil & 65 & 55 & 45 & 55 & 45 \\
Salt-B & 5 & 5 & 5 & 5 & 5 \\
Vitamin mix & 4 & 4 & 4 & 4 & 4 \\
Choline chloride & 1 & 1 & 1 & 1 & 1 \\
DAC & 0.15 & 0.15 & 0.15 & 0.15 & 0.15 \\
& - & - & - & 10 & 20
\end{tabular}

Nitrogen content $(\%) \quad 3.46 \quad 4.82 \quad 6.23 \quad 4.66 \quad 5.99$

1) Fat soluble vitamins were mixed in soybean oil to provide the following amounts: vitamin A, $6000 \mathrm{IU}$; vitamin D, $600 \mathrm{IU}$ and $\alpha$-dl-tocopherol, $100 \mathrm{mg}$ per $\mathrm{kg}$ diet, respectively.

2) These were essentially the same as Harper's mitures (A. E. Harper, J. Nutrition, 68, 405 (1959)).

respective test diets shown in Table I. After 9 days of the feeding, the rats were killed and arginase assay was performed as described above. Urine was collected for the last 2 days.

Experiment 3. The purpose of this experiment was to confirm the previous observation ${ }^{4}$ - - the consistent effect of dietary amino acid balance on the inverse relationship between liver arginase activity and urea excretion. In this experiment, amino acid mixture was a sole source of dietary nitrogen. Standard amino acid composition of the mixture was identical with the minimum requirement pattern revorted by Rama Rao et al.,213 which supported the maximum growth of weanling rats. In order to change the amino acid balance quantitatively in a chemical sense, only one essential amino acid (threonine) in the mixture was varied stepwise in quantity, from suboptimal to supraoptimal levels as indicated in Fig. 5.

After weanling male rats of Wistar strain $(40 \sim 50 \mathrm{~g})$ had been standardized for one week by feeding the $20 \%$ casein diet, 35 rats were selected on the basis of body weight and the rate of gain, divided into 7 groups, and given the test amino acid diets for 10 days. Nonprotein group was also included to calculate

21) P. B. Rama Rao, H.W. Norton, and B.C. Johnson, $J$. Nutrition, 73, 38 (1961). the net protein ratio22! and the biological value. ${ }^{23}$ At the end of the test period, the animals were sacrificed by decapitation. Enzyme assay and urea determination were performed as made in experiment 1. The data on urea excretion (in Fig. 5) are those obtained from the urine samples collected for the last 3 days of test period.

\section{RESULTS}

\section{Experiment 1 .}

In the first $24 \mathrm{hr}$ of the test period, growth retardation was observed in the groups receiving various DAC levels and the degree of retardation was roughly proportional to the level of DAC included. On the second day, each group was restored and grew afterward at a constant rate. All animals gained their boday weight almost linearly, although the

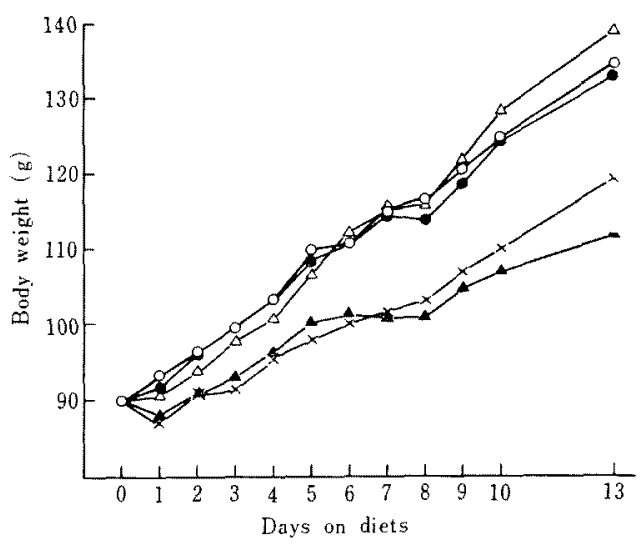

FIG. 1. Changes in Body Weight of the Rats Fed the $8 \%$ Casein Diets Containing Various Levels of Diammonium Citrate.

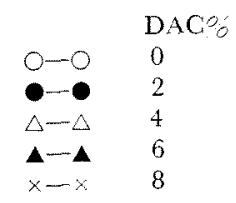

22) A. E. Bender and B. H. Doell, Brit. J. Nutriion, 11, 140 (1957).

23) L. R. Njaa, ibid., 13, 137 (1959). 
Table II. Liver Arginase Activities and Urea Excretions in Rats fed $80^{\circ}$ Casein Diet Containing Graded levels of Diammonium Citrate

\begin{tabular}{|c|c|c|c|c|c|c|}
\hline \multirow[b]{2}{*}{ DAC levell } & \multicolumn{3}{|c|}{ Liver arginase } & \multirow[b]{2}{*}{$\begin{array}{l}\text { Urea } \\
\text { excretion } \\
\text { (b) }\end{array}$} & \multirow[b]{2}{*}{$\begin{array}{c}\text { T. A./urea } \\
(\mathrm{a} / \mathrm{b})\end{array}$} & \multirow[b]{2}{*}{$\begin{array}{c}\text { Relative } \\
\text { value of } \\
\text { T. A./urea }\end{array}$} \\
\hline & $\begin{array}{c}\text { Specific } \\
\text { activity } \\
\text { I }\end{array}$ & $\begin{array}{c}\text { Specific } \\
\text { activity } \\
\text { II }\end{array}$ & $\begin{array}{l}\text { Total } \\
\text { activity } \\
\text { (a) }\end{array}$ & & & \\
\hline 9 & $\begin{array}{l}\mathrm{mg} \text { urea/g } \\
\text { liver } / 5 \mathrm{~min}\end{array}$ & $\begin{array}{l}\mathrm{mg} \text { urea } / \mathrm{mg} \\
\mathrm{N} / 5 \mathrm{~min}\end{array}$ & $\begin{array}{l}\text { mg urea/ } \\
\text { liver } / 5 \mathrm{~min}\end{array}$ & $\mathrm{mg} / \mathrm{day} / \mathrm{rat}$ & & \\
\hline 0 & $55.8 \pm 2.58^{\mathrm{b}, 2}$ & $2.16 \pm 0.079$ & $303 \pm 20.6^{a}$ & $75.2 \pm 2.59 \mathrm{a}$ & $4.04 \pm 0.263$ & $100 \pm 6.50 \mathrm{a}$ \\
\hline 2 & $58.8 \pm 4.53$ & $2.28 \pm 0.155$ & $290 \pm 31.5^{\mathrm{a}}$ & $136 \pm 6.49 \mathrm{~b}$ & $2.18 \pm 0.132^{b}$ & $54.0 \pm 3.27$ \\
\hline 4 & $59.1 \pm 2.20^{\mathrm{s}}$ & $2.16 \pm 0.081^{\mathrm{a}}$ & $308 \pm 11.2^{\mathrm{a}}$ & $\pm 13.2 \mathrm{c}$ & $1.26 \pm 0.059 c$ & $31.2 \pm 1.44^{\mathrm{c}}$ \\
\hline 6 & $49.9 \pm 3.36 \mathrm{bb}$ & $1.81 \pm 0.113^{b}$ & $209 \pm 16.2^{b}$ & $\pm 14.0 \mathrm{c}$ & $0.92 \pm 0.100^{d}$ & $22.7 \pm 2.47 \mathrm{~d}$ \\
\hline 8 & $48.2 \pm 2.30^{\circ}$ & $1.65 \pm 0.105^{\mathrm{b}}$ & $196 \pm 9.3^{b}$ & $324 \pm 10.3^{\mathrm{d}}$ & $0.6 \mathrm{l} \pm 0.027 \mathrm{e}$ & $15.0 \pm 0.67 \mathrm{e}$ \\
\hline
\end{tabular}

1) DAC is the abbreviation for diammonium citrate.

2) S. E. of the mean and figures with different alphabetical superscripts are significantly different $(\mathrm{P}<0.001-0.05)$.

growth rates of the rats fed the 6 to $8.0 \mathrm{DAC}$ diets were relatively small compared with those fed 2 or $4 \%$ DAC diets (Fig. 1).

As seen in Table II, urea excretion increased with increasing $\mathrm{DAC}$ level in the diet. Inclusion of only $2.6 \mathrm{DAC}$ in the basal diet doubled urea excretion, 4 to $6 \%$ DAC tripled and $8 \%$ DAC almost quadrupled. The proportionality between dietary DAC level and urea excretion suspended at $6 \%$ level of DAC, because of the moderate reduction in food intake.

Specific activity I and II for liver arginase of the rats receiving 6 or $8 \% \mathrm{DAC}$ diet were considerably lower than those of basal or 2 to $4 \%$ DAC diet-fed rats. Total liver arginase activities (expressed as $\mathrm{mg}$ urea formed $/ 5 \mathrm{~min}$ / liver) in the rats fed $0 \sim 4 \%$ DAC were significantly higher than those in rats fed 6 or $8 \%$ DAC. Thus, it was again observed that total liver arginase activity inversely decreased with the increased urea excretion as already observed in the previous studies. ${ }^{4}$ In Table II and Fig. 2, this relationship is expressed as the ratio of total activity to urea excretion, showing the marked decrease along with DAC level in diet: increased urea excretion was not a direct result from increased total activity of liver arginase (Fig. 2).

In experiment $2,25 \%$ casein diet containing

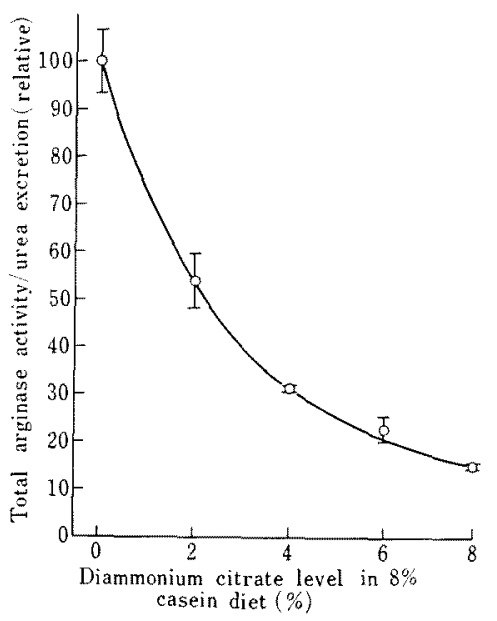

FIG. 2. The Ratios of Total Liver Arginase Activity to Urea Excretion Plotted against Dietary Diammonium Citrate Level.

$20 \%$ DAC caused exceptionally a marked growth retardation for the first 3 days, but the growth of this group was restored thereafter and progressed linearly. The growth rates of other all groups were approximately the same (Fig. 3). The addition of DAC at $10 \%$ level did not cause such an initial growth lag, being probably due to high basal level of casein, although the weight gain of this group was slightly lower than that of the 


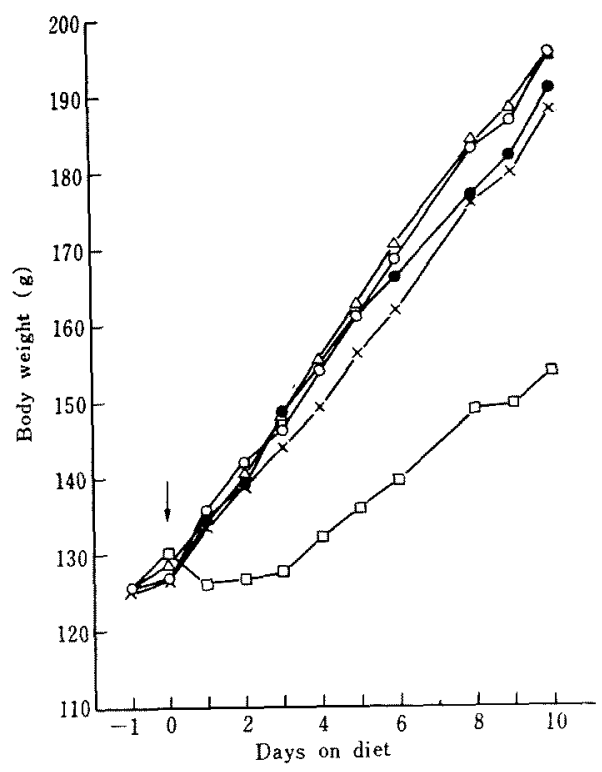

FIG. 3. Changes in Body Weight of the Rats Fed Various Levels of Casein and Diammonium Citrate.

$$
\begin{aligned}
& 0-0 \quad 25 \% \text { Cas. } \\
& -\quad 35 \% \text { Cas. } \\
& \Delta-\triangle 45 \% \text { Cas. } \\
& x-\times 25 \% \text { Cas. }+10 \% \text { DAC } \\
& \square-\square \quad 25 \% \text { Cas. }+20 \% \text { DAC }
\end{aligned}
$$

rats fed the $25 \%$ casein basal diet.

Total liver arginase activity consistently increased when the dietary casein level increased from 25 to $45 \%$, although the increases in specific activity I and II were relatively small (Table III). However, the rate of the increase in urea excretion preceded that in the enzyme activity, and thence the ratio of total liver arginase activity to urea excretion rather decreased to some extent. On the other hand, the addition of $\mathrm{DAC}$ resulted in striking decreases in arginase activity expressed in 3 ways (Table III). Urea excretion of rats fed DAC were significantly higher than that of rats fed $25 \%$ casein basal diet and almost the same as much as that of $35 \%$ casein group. These situations are reflected on the ratio of total arginase activity to urea excretion: it was again shown that urea excretion increased without concerted elevation of liver arginase level in the rats fed DAC containing diet (Fig. 4 and Table III). This is apparently analogous to the responses to the changes in dietary protein quality.

In experiment 3 , body weight gain per 9 days increased with the increase of threonine level in diet and reached a maximum value at $0.38 \%$ level of threonine. Below the $0.13 \%$ level of threonine, the rats lost weight and

\begin{tabular}{|c|c|c|c|c|c|c|}
\hline \multirow[b]{2}{*}{ Diet } & \multicolumn{3}{|c|}{ Liver arginase } & \multirow{2}{*}{$\begin{array}{l}\text { Urea } \\
\text { excretion } \\
\text { (b) }\end{array}$} & \multirow{2}{*}{$\begin{array}{l}\text { T. A./urea } \\
(\mathrm{a} / \mathrm{b})\end{array}$} & \multirow{2}{*}{$\begin{array}{l}\text { Relative } \\
\text { value of } \\
\text { T. A./urea }\end{array}$} \\
\hline & $\begin{array}{c}\text { Specific } \\
\text { activity } \\
\text { I }\end{array}$ & $\begin{array}{c}\text { Specific } \\
\text { activity } \\
\text { II }\end{array}$ & $\begin{array}{c}\text { Total } \\
\text { activity } \\
\text { (a) }\end{array}$ & & & \\
\hline & $\begin{array}{l}\mathrm{mg} \text { urea/g } \\
\text { liver } / 5 \mathrm{~min}\end{array}$ & $\begin{array}{l}\mathrm{mg} / \mathrm{urea} / \mathrm{mg} \\
\mathrm{N} / 5 \mathrm{~min}\end{array}$ & $\begin{array}{l}\text { mg urea/ } \\
\text { liver } / 5 \text { min }\end{array}$ & $\mathrm{mg} / \mathrm{day} / \mathrm{rat}$ & & \\
\hline A & $91.3 \pm 7.04 a, 1)$ & $3.12 \pm 0.220^{a}$ & $865 \pm 68.1^{\mathrm{a}}$ & $733 \pm 62.2^{a}$ & $1.19 \pm 0.053^{\mathrm{a}}$ & $100 \pm 4.5$ \\
\hline $\mathrm{B}$ & $103 \pm 6.23 \mathrm{a}$ & $3.42 \pm 0.212^{\mathrm{a}}$ & $941 \pm 61.3$ & $1104 \pm 44.0^{b}$ & $0.85 \pm 0.043^{\mathrm{b}}$ & $71.5 \pm 3.6^{\circ}$ \\
\hline C & $105 \pm 5.99 \mathrm{a}$ & $3.51 \pm 0.168^{\mathrm{a}}$ & $1055 \pm 74.4^{a}$ & $1407 \pm 23.3 \mathrm{e}$ & $0.75 \pm 0.045^{b}$ & $63.0 \pm 3.8^{b}$ \\
\hline $\mathrm{D}$ & $62.1 \pm 2.77 \mathrm{~b}$ & $2.09 \pm 0.093 \mathrm{~b}$ & $545 \pm 26.5^{b}$ & $1041 \pm 28.7 \mathrm{~b}$ & $0.53 \pm 0.026^{c}$ & $44.5 \pm 2.2^{c}$ \\
\hline $\mathrm{E}$ & $54.4 \pm 3.40^{\circ}$ & $1.74 \pm 0.106^{c}$ & $391 \pm 22.0 \mathrm{e}$ & $1090 \pm 45.4^{b}$ & $0.36 \pm 0.019^{d}$ & $30.1 \pm 1.7^{\mathrm{d}}$ \\
\hline
\end{tabular}
the entire deletion of threonine led to more

Table III. Liver ARginase ACtivities and URea Excretions in Rats Fed $25 \%$ Casein DIET AdDitionally SUPPlemented with Various levels of Casein or Diammonium Citrate (Exp. 2)

1) S.E. of the mean and figures with different alphabetical superscripts are significantly different $(\mathrm{P}<0.001-0.05)$. 


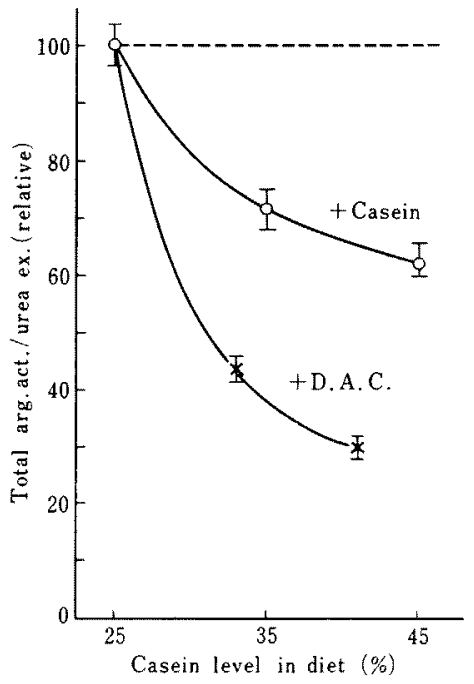

FIG. 4. The Ratios of Total Liver Arginase Activity to Urea Excretion Plotted against the Dietary Levels of Casein and Diammonium Citrate.

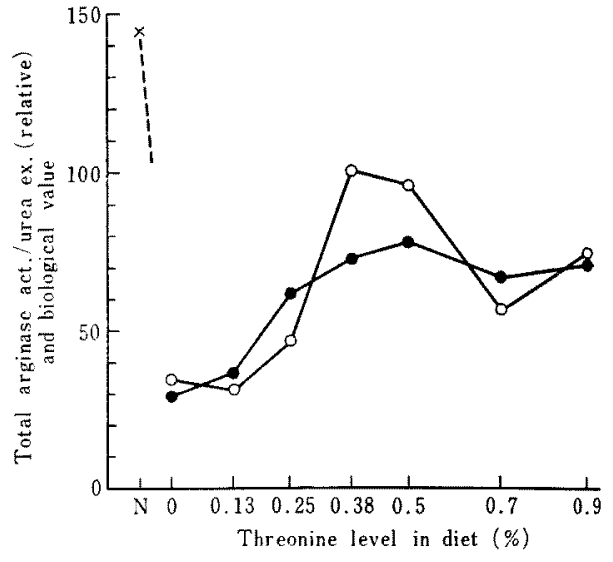

FIg. 5. Total Liver Arginase Activity per Unit Urea Excretion, $\mathrm{O}-\mathrm{O}$, and Biological Values, from Rats Fed the Amino Acid Diets Containing Graded Levels of Threonine.

$X:$ An average value of total liver arginase activity per urea excretion in rats fed nonprotein diet for 10 days.

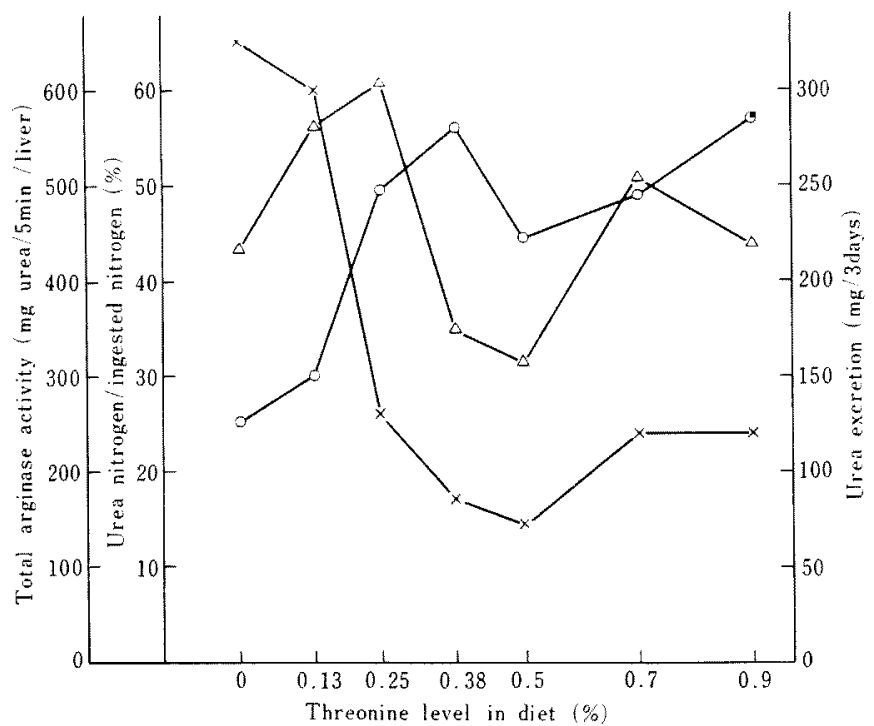

FIG. 6. Total Liver Arginase Activity, $O-O$; Urea Excretion, $\Delta-\Delta$; and Urea Nitrogen per Ingested Nitrogen, $x-x$ in the Rats Fed Amino Acid Diets Containing Graded Levels of Threonine. 
severe weight loss than in nonprotein group.

The protein efficiency ratio and the net protein ratio during 9 days gave maximum values at $0.38 \%$ level of threonine as well as in weight gain per 9 days, through the biological value was the highest at $0.5 \%$ threonine level (in Fig. 5, only the latter values are presented).

The curves in Fig. 6 represent the changes in urea excretion, nitrogen excreted as urea per unit amount of ingested nitrogen, and total liver arginase activity of rats fed the amino acid diets containing the different levels of threonine. Urea excretion greatly decreased at $0.38 \%$ or $0.5 \%$ threonine levels, regardless of higher food intakes in rats fed these diets. On the other hand, total liver arginase continuously increased up to $0.38 \%$ level of threonine. Thus, urea excretion is inversely related to the total liver arginase activity and the dietary protein quality. As shown in Fig. 5, the ratio of the total arginase activity to the urea excretion increased with the improvement of nutritive value of the amino acid mixtures as expressed in terms of biological value or net protein ratio, etc. Within the range from zero to $0.38 \%$ threonine level, total liver arginase activity changes in parallel with body weight gain, the protein efficiency ratio, the net protein ratio or the biological value. Relatively high specific activity of liver arginase in zero per cent threonine group is possibly attributed to the moderate caloric deficiency caused by reduced food intake in the animals eating such an extremely unbalanced amino acid mixture.

\section{DISGUSSION}

In rats, urea excretion linearly increased with the increase of dietary casein level over the range from 10 to $60 \%,,^{3,241}$ and these changes in urea excretion are also accompanied

24) K. Muramatsu and K. Ashida, Nippon Nogeikagaku Kaishi, 31, 607 (1957). by the proportional increases in liver arginase activity. Since this relationship has been well-founded, there is a hasty generalization that total liver arginase activity changes depending upon the needs for urea excretion. In such a case, however, the nitrogen excreted as urea would be derived mainly from the surplus fraction of amino acids which are supplied beyond utilizing rate for synthetic purposes and beyond the requirements or retaining capacity of animals, and the animals are guaranteed, at any time, from the shortage of the raw materials for the synthesis of body protein and/or of arginase protein. Consequently, a concurrent increase both in urea excretion and in arginase activity would result.

Recent experimental evidences reported by Muramatsu and Ashida, ${ }^{25)}$ Kiriyama et al., and $\mathrm{Kean}^{261}$ can not be construed by a "purpose-ful" explanation. The data of Muramatsu and Ashida ${ }^{25)}$ shows that when rats were fed various natural proteins having widely different qualities, liver arginase activity increased linearly along with the dietary protein level and the urea excretion within the same protein group, but the activity was always higher in rats fed high quality protein, accompanying less urea excretion. Similar observations were reported by Kiriyama et al.," using amino acid mixture as a sole $N$ source of which quality was varied stepwise by changing the level of only one essential amino acid (tryptophan). These results also indicate that the ratio of arginase activity in vitro to urea excretion changes proportionately to the protein quality.

When rats were fed the diets containing constant level (about 10\%) of different proteins or amino acid mixtures, the extra excretion of urea $\mathrm{N}$ may be produced as a result of inevitable degradation of unbalanced, unutilized fraction of amino acids from dietary

25) K. Muramatsu and K. Ashida, Proc. Symposium on Chem. Physiol. and Pathol., 2, 169 (1962)

26) E. A. Kean, Brit. J. Nutrition, 21, 29 (1967). 
protein. In this case, therefore, the larger the urea excretion, the poorer is, as a whole, the available amino acids for body protein synthesis. This suggests possible relationship that, when dietary protein level barely satisfies the protein requirement, the arginase-protein synthesis would become more limited or its degradation is enhanced as the amino acid unbalance grows more serious. When only the DAC level in diet was varied at a constant protein level, arginase activity did not increase even though urea excretion greatly increased (experiments $\mathrm{I}$ and 2). This may be explained in part from the fact that in these animals amino acid supply never increased above basal level (8 or $25 \%$ casein). Thus, the effect of the changes both in protein level and quality on the urea excretion is alike in appearance but different in metabolic situation. It may be the different metabolic situation which also exerts different effect on the liver arginase activity. From these facts, it appears that liver arginase level changes depending chiefly upon the rate and amount of amino acid supply into the liver and the coexistence of sufficient amounts of all amino acids seems to be needed to induce such an increased liver arginase activity.

Schimke ${ }^{271}$ and Schimke et al. ${ }^{28}$ revealed that rat liver arginase and tryptophan pyrrolase levels are determined by the balance of the rates in enzyme degradation and enzyme synthesis. However, it appears that liver arginase is synthesized whenever body protein retention is generally enhanced (as shown by Freedland and Sodikoff ${ }^{291}$ and the present authors $^{15)}$ to be related to animal's body weight

27) R. T. Schimke, J. Biol. Chem., 239, 3808 (1964).

28 R. T. Schimke, E. W. Sweeney, and C. M. Berlin, ibid., 240, 322 (1965).

29) R. A. Freedland and C. H. Sodikoff, Proc. Soc. Exp. Biol. Med., 109, 394 (1962). gain or biological value of dietary protein) and whenever larger quantities of amino acids flow into the liver from other organs or from dietary origin (as expected in the case of fasting or feeding of high protein diet).

If the level of liver arginase adaptively changes depending upon the degree of body's need for urea biosynthesis, the enzyme activity should be elevated even when the urea excretion was increased by any other means than increasing the dietary protein level; the increased urea excretion induced by $\mathrm{DAC}$ feeding must naturally be accompanied by an appreciable elevation in arginase activity. However, this is not the case and, in fact, total liver arginase activity changes inversely with urea excretion (experiments 1 and 2).

The total liver arginase level would greatly exceed the amounts being required for urea formation and, in in vitro experiments, arginase appears to be the most abundant enzyme in the urea-cycle. ${ }^{31}$ Under ordinary physiological conditions, thus, the amounts of the substrates (mainly $\mathrm{NH}_{3}$ ) flowing into the urea cycle would be responsible for the changes in urea excretion. If the dietary protein level is constant, arginase activity can not be increased above an initial level but rather decreases even when urea excretion rate is greatly accelerated by feeding DAC or amino-acid unbalanced diet, because total amino acid supply to liver remains, more or less, constant and the amount of available amino acids for protein synthesis becomes relatively restricted by the degree of amino acid unbalance.

From the present and previous results, the early teleological assumptions are most unlikely in that liver arginase activity may increase with the decreasing nutritive quality of dietary protein, and that the change in arginase activity may be of use as an index of dietary protein quality. 